\title{
Removal of copper(II) from aqueous solution by non-living Oscillatoria sp.
}

\author{
D. Singh \\ Department of Civil Engineering \\ National Institute of Technology, Kurukshetra, India
}

\begin{abstract}
The performance of dried green alga Oscillatoria $s p$. to remove $\mathrm{Cu}(\mathrm{II})$ from aqueous solution was investigated as a biosorbent. The non-living algal biomass was found to remove copper ions efficiently. The rate of biosorption was affected by contact time, $\mathrm{pH}$, initial copper ion concentration and temperature. Optimal initial $\mathrm{pH}$ for $\mathrm{Cu}(\mathrm{II})$ sorption was found to be 4 . The uptake of $\mathrm{Cu}(\mathrm{II})$ by algal biomass is very rapid in the initial contact time. Metal uptake capacity was observed to be increasing with an increase in initial metal ion concentrations. Temperature has a positive effect on the biosorption of the copper by Oscillatoria $s p$. The experimental data fitted well in both the Freundlich and Langmuir isotherms $(R 2>0.98) . Q_{\max }$ obtained from the Langmuir isotherms was found to be $36.2 \mathrm{mg} / \mathrm{g}$. The sorbed copper ions were effectively desorbed using $0.1 \mathrm{~N} \mathrm{HCl}$.

Keywords: removal, biosorption, Oscillatoria sp., contact time, $\mathrm{pH}$, metal uptake, desorption, temperature.
\end{abstract}

\section{Introduction}

Widespread concern over the cumulative toxicity and environmental impact of heavy metals has led to extensive research into developing effective alternative technologies for the removal of these potentially damaging substances from effluents and industrial wastewaters. The potential sources of copper in effluents include copper mining operations, smelters, iron foundries metal cleaning and plating baths, pulp, paper board mills, wood pulp production, and fertilizer; industry, etc. [1, 2]. Copper may be found as a contaminant in food, water or drink because any processing or container using copper may contaminate these products [3]. Although copper is an essential element, large acute doses can 
produce harmful even fatal effects [2]. Methods available for the removal of metal ions from aqueous solutions include ion exchange, solvent extraction, reverse osmosis, electrodialysis, precipitation, flocculation and membrane separation processes. Most of these techniques have certain demerits such as high capital and operational costs, disposal or treatment of the residual metal sludge. These processes are ineffective, especially when the metal concentrations are very low and of the order of 1 to $100 \mathrm{mg} / \mathrm{l}$ in the solution [4]. Biosorption is a promising alternative, which utilizes inactive or dead biomass to bind and concentrate heavy metals from the aqueous solutions. Present investigation is devoted to study the removal of $\mathrm{Cu}$ (II) from synthetics aqueous wastewater by using non-living Oscillatoria sp. (a fresh water alga) by batch experiments. The parameters which influence biosorption process such as contact time, $\mathrm{pH}$, initial metal ion concentration, algal dose and temperature were studied.

\section{Materials and methods}

Analytical grade reagents were used in all experiments and double distilled water was used throughout. Stock metal solution (1000 mg/l) was prepared by dissolving $1.000 \mathrm{~g}$ of copper metal (NICE make, Cochin) in minimum volume of (1:1) $\mathrm{HNO}_{3}$. It was diluted to one litre with $1 \%(\mathrm{~V} / \mathrm{V}) \mathrm{HNO}_{3} . \mathrm{Cu}$ (II) working solutions were made freshly by diluting the stock solutions. Algal biomass of Oscillatoria sp. was collected from local tanks. It was washed under running tap water and was followed by washing with double distilled water to remove extraneous matter. The washed biomass was sun dried and ground to powder in the laboratory pulverizer. The powdered biomass passing through I.S. Sieve No. 30 and retained on I.S. Sieve No. 15 was selected for this study. All the experiments, except studies related to the effect of temperature, were conducted at room temperature $\left(28 \pm 2^{\circ} \mathrm{C}\right)$.

\subsection{Procedure adopted for $\mathrm{Cu}(\mathrm{II})$ biosorption studies}

$100 \mathrm{ml}$. of copper metal ion solution of a required concentration $(\mathrm{mg} / \mathrm{l})$ was taken in Erlenmeyer flask (250 ml. size). To this solution selected algal dose ( $\mathrm{g} / \mathrm{l})$ was added and it was put on the rotary shaker $(140 \mathrm{rpm})$. After the desired contact time, the sample was taken out and filtered through Whatman 41 filter paper. The filtrate was analyzed for residual metal ion concentration using Atomic Absorption Spectrophotometer. (Model AAS-4129, ECIL, India).

\section{Results and discussions}

\subsection{Effect of contact time}

An ideal biosorbent should rapidly sorb high concentration of metal ions from aqueous solution [5]. Considering this, the effect of contact time on the percentage removal of $\mathrm{Cu}$ (II) by biosorption from synthetic solutions with initial $\mathrm{Cu}$ (II) concentrations of $10 \mathrm{mg} / \mathrm{l}$ using the algal dose of $5 \mathrm{~g} / \mathrm{l}$ was studied and 
results are shown in Figure 1. The uptake of $\mathrm{Cu}(\mathrm{II})$ by algal biomass is very rapid in the initial contact time of 10 minutes (80-90\% of uptake at equilibrium). It can be observed that maximum percentage removal of $\mathrm{Cu}$ (II) was achieved within a period of 100-120 minutes. Therefore, for the following experiments, the contact time was taken as 120 minutes.

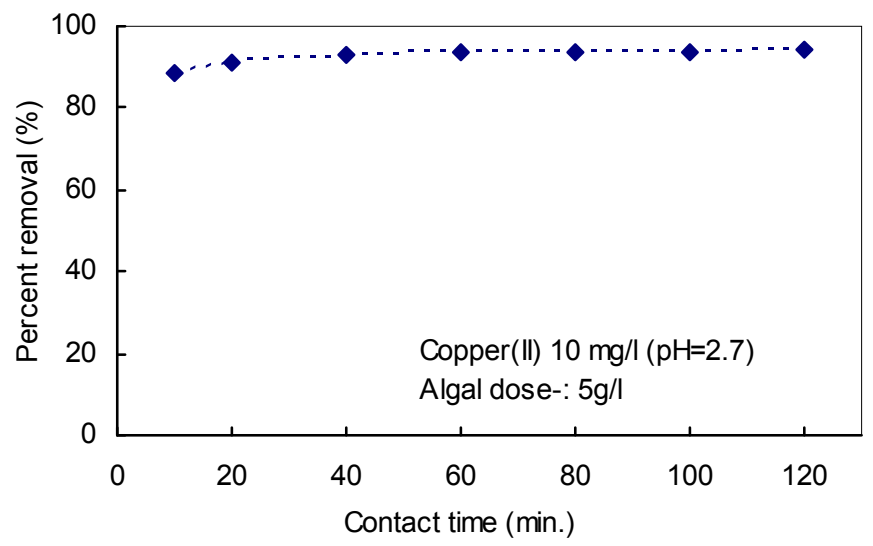

Figure 1: $\quad$ Effect of contact time on removal of copper(II).

\subsection{Effect of initial pH values}

Metal biosorption is critically linked with $\mathrm{pH}$. In order to establish the effect of $\mathrm{pH}$ on the sorption of $\mathrm{Cu}(\mathrm{II})$ onto algal biomass, experiments were conducted on $\mathrm{Cu}$ (II) solutions of $10 \mathrm{mg} /$ in the $\mathrm{pH}$ range of 1-12 at an algal dose of $5 \mathrm{~g} / \mathrm{l}$ (Figure 2). Maximum $\mathrm{Cu}$ (II) removal was observed as $94.8 \%$ at $\mathrm{pH}$ value of 4.0 .

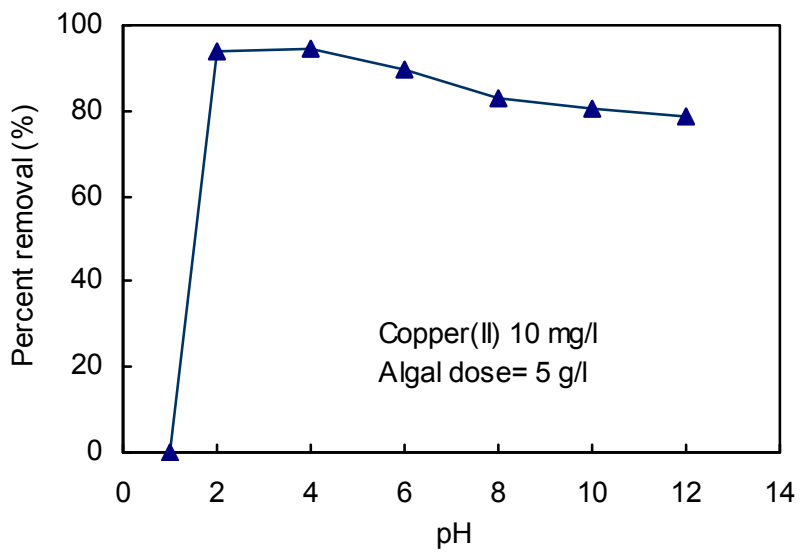

Figure 2: $\quad$ Effect of initial $\mathrm{pH}$ on removal of copper(II). 
Beyond $\mathrm{pH} 4.0$, it decreased progressively. The results indicated that the copper biosorption by non-living cells of algae was affected by initial $\mathrm{pH}$ of the solution and may be due to ionic attraction. Copper will transform into hydroxide complex at higher $\mathrm{pH}$ and could not be considered for biosorption behaviour of the cells [6].

\subsection{Effect of algal dose and initial metal ion concentration}

Figure 3 shows the effect of algal dose and initial metal ion concentration on the removal of $\mathrm{Cu}$ (II) by biosorption. It is evident from figure that the lower algal dose (1-4 g/l) was more effective for all the initial concentrations of copper removal. Beyond $6 \mathrm{~g} / \mathrm{l}$ algal dose, it was slowed down; a further increase in algal dose couldn't cause any appreciable increase in the rate of metal removal. These results clearly indicate that the removal efficiency increases up to the optimum dosage beyond which the increase in removal efficiency is negligible. It is apparent that the equilibrium metal ion concentration decreases with increasing algal dosage for a given initial metal concentration. This is to be expected because, for a fixed initial solute concentration, increasing sorbent doses provides greater surface area or sorption sites. However, after optimal dose sorption sites were not easily accessible and making sorption rate almost constant. Metal uptake, $q_{e q}$ (mg of metal ion uptake per $\mathrm{g}$ of alga at equilibrium) is shown in Figure 4. It can be seen that the metal uptake showed a decreasing trend i.e. high metal uptake at lower algal doses and lower uptake at higher algal doses. In other words, though the metal removal is directly proportional to the increase in algal dose but metal uptake by algal biomass is inversely proportional to the increase in algal dose from the metal solution.

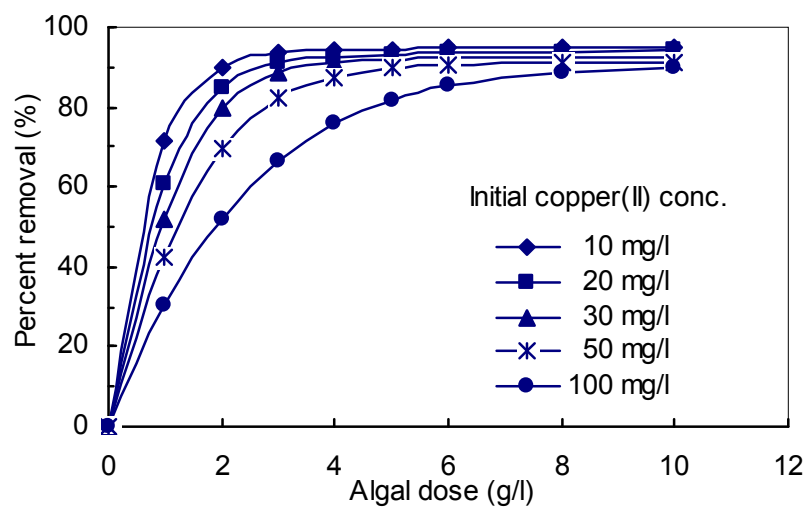

Figure 3: $\quad$ Effect of algal dose on copper(II) removal at initial $\mathrm{pH} 4.0$. 


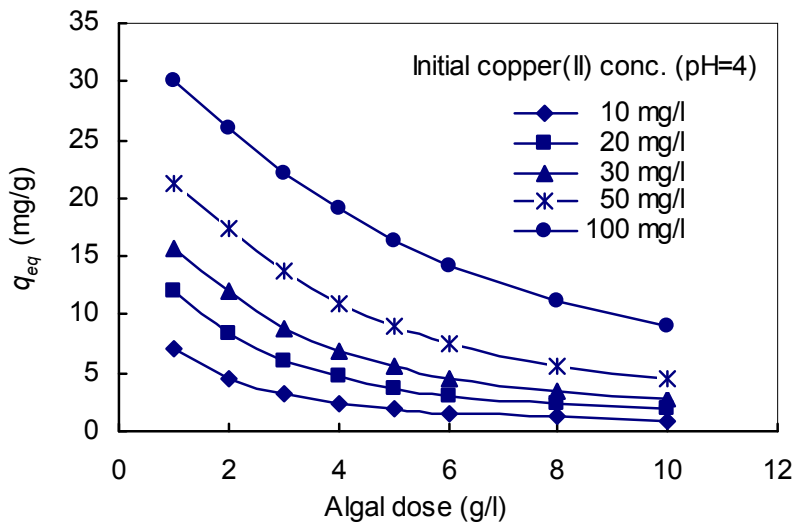

Figure 4: $\quad$ Effect of algal dose and initial copper ion concentration on specific update $\left(q_{e q}\right)$.

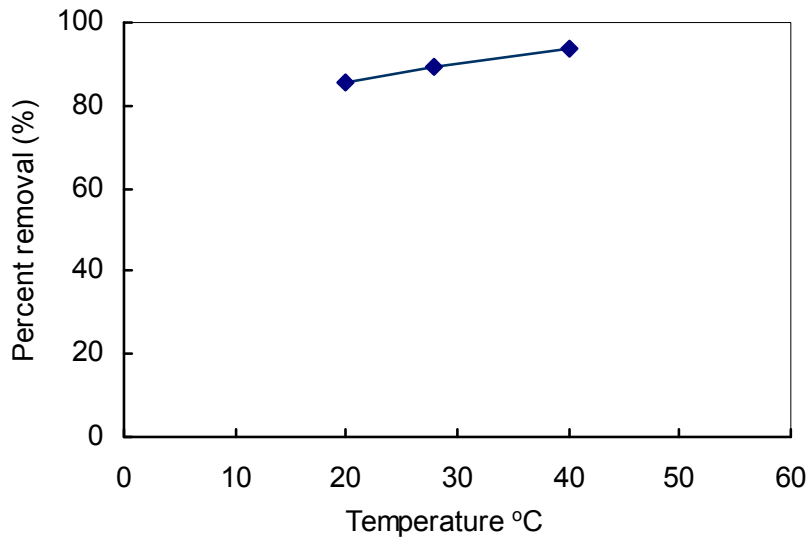

Figure 5: $\quad$ Effect of temperature on removal of copper(II).

\subsection{Effect of temperature}

Effect of temperature on biosorption of $\mathrm{Cu}$ (II) by Oscillatoria sp. was studied at three temperatures $\left(20^{\circ} \mathrm{C}, 28^{\circ} \mathrm{C}\right.$ and $\left.40^{\circ} \mathrm{C}\right)$. Initial metal ion concentration, $\mathrm{pH}$ and algal dose were kept as $10 \mathrm{mg} / 1,4.0$ and $2.0 \mathrm{~g} / 1$ respectively. It can be seen that high temperature enhanced the copper(II) biosorption by algal biomass (Figure 5). Temperature affects a number of factors that are important for metal biosorption. These include the stability of the metal ion species; the ligands and ligand metal complex as well as the solubility of the metal ions. In general, higher temperature favors greater solubility of metal ions in solution and hence 
weakens the biosorption of the metals ions [7]. Thermodynamically, biosorption will be favored by high temperature if the binding is endothermic but weakened if it is exothermic. The favoring or not by high temperature for the biosorption process is, therefore, dependent on the relative contribution of the carboxylate or amine-ligands on the cell wall/surface. The overall effect of temperature would therefore be the total sum of these favoring and unfavoring factors.

\section{Adsorption isotherms}

Freundlich and Langmuir isotherms were used for defining the equilibrium of sorption of $\mathrm{Cu}(\mathrm{II})$ on Oscillatoria sp. The experimental data obtained fitted well $\left(R^{2}>0.98\right)$ in both the Freundlich and Langmuir isotherms (Figures 6 and 7). The

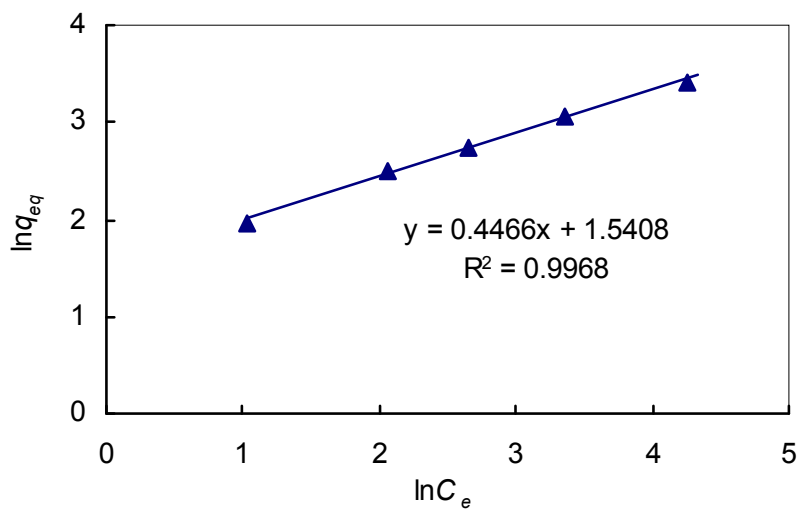

Figure 6: The linearized Freundlich sorption isotherms of copper(II) by Oscillatoria sp. (1g/l) at initial pH 4.0.

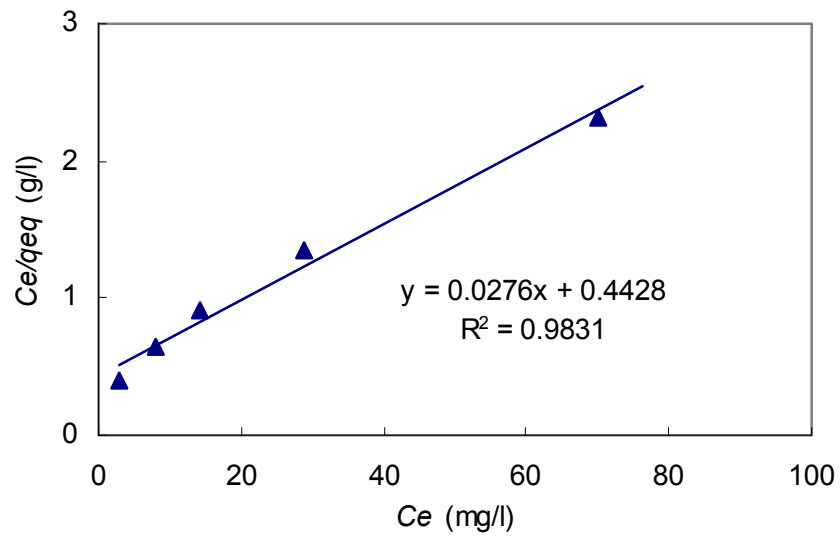

Figure 7: The linearized Langmuir sorption isotherms of copper(II) by Oscillatoria sp. $(1 \mathrm{~g} / \mathrm{l})$ at initial $\mathrm{pH} 4.0$. 
applicability of both the isotherm models implies that both monolayer biosorption and heterogeneous surface conditions exist under the experimental conditions used. The biosorption of $\mathrm{Cu}$ (II) on algal biomass is thus complex involving more than one mechanism. $Q_{\max }$ (Maximum possible amount of metallic ions uptake per unit weight of biosorbent, $\mathrm{mg} / \mathrm{g}$ ) obtained from the Langmuir isotherms was found to be $36.2 \mathrm{mg} / \mathrm{g}$.

\section{Desorption of copper(II)}

Recovery of the metal ions sorbed onto the biomass is one of the important aspects of any successful biosorption process development [8]. In the present study, $0.1 \mathrm{~N} \mathrm{HCl}$ was used to desorb metal ions. The recovery of $\mathrm{Cu}(\mathrm{II})$ sorbed was found to be $96.6 \%$.

\section{Conclusions}

The batch studies conducted in the present study indicated that Oscillatoria $s p$. is an effective biosorbent and has potential for removal of copper from aqueous solutions. Biosorption of $\mathrm{Cu}(\mathrm{II})$ depended on contact time, $\mathrm{pH}$, initial metal ion concentration and temperature. Maximum copper removal by algal biomass was at $\mathrm{pH}$ 4.0. The applicability of both the isotherm models implies that both monolayer biosorption and heterogeneous surface conditions exist under the experimental conditions used. Desorption of the sorbed $\mathrm{Cu}$ (II) by $0.1 \mathrm{~N} \mathrm{HCl}$ indicated that recovery of $\mathrm{Cu}(\mathrm{II})$ from spent biomass is possible..

\section{References}

[1] Nuhoglu, Y. \& Oguz, O., Removal of copper(II) from aqueous solutions by biosorption on the cone biomass of Thuja orientalis, Process Biochemistry, 38, pp. 1627-1631, 2003.

[2] Vilar, Vitor J.P., Botelho, Cidalia M. S. \& Boaventura, Rui A.R., Copper removal by algae Gelidium, agar extraction algal waste and granulated algal waste: Kinetoics and equilibrium, Bioresource Technology, 99(4), pp. 750$762,2007$.

[3] Nuhoglu, Y., Malkoc, E., Gurses A. \& Canpolat N., The removal of Cu(II) from aqueous solutions by Ulothrix zonata, Bioresource Technology, 85(3), pp. 331-333, 2002.

[4] Volesky, B. Biosorption of Heavy Metals, CRC press, Boca Raton, USA, pp. 3, 1990.

[5] Singh, Apana, Kumar, Dhananjay \& Gaur, J.P., Copper(II) and lead(II) sorption from aqueous solutions by non-living Spirogyra neglecta, Bioresource Technology, 98(18), pp. 3622-3629, 2007.

[6] Chen, X.C., Wang, Y.P., Lin, Q., Shi, J.N., Wu, W.X. \& Chen, Y.X., Biosorption of Copper(II) and Zinc(II) from aqueous solution by 
340 Sustainability Today

Pseudomonas putida CZI, Colloids and Surfaces B. Binterfaces. 46, pp.101107, 2005.

[7] Lau, P.S., Tsang, C.C.K., Tam, N.F.Y. \& Wong, Y.S., Effect of Metal Interference, $\mathrm{pH}$ and Temperature on $\mathrm{Cu}$ and $\mathrm{Ni}$ Biosorption by Chlorella vulgaris and Chlorella miniata., Environmental Technology. 20, 953-961, 1999.

[8] Sar, P., Kazy, S.K., Asthana, R.K \& Singh, S.P., Metal adsorption and desorption by lyophilized Pseudomonas Aeruginosa, International Biodeterioration \& Biodegradation, 44, 101-110, 1999. 